\title{
The Impact of Age, Gender and Body Mass Index on the Polysomnography Variables
}

\section{Yaș, Cinsiyet ve Vücut Kitle Indeksinin Polisomnografideki Değișkenlere Etkisi}

\author{
(1) Sıdıka Deniz Yalım \\ Adana City Training and Research Hospital, Clinic of Otolaryngology, Adana, Turkey
}

\begin{abstract}
Objective: This study aimed to analyse respiratory parameters in polysomnography, mean nocturnal pulse oxyhaemoglobin saturation (mean nocturnal $\mathrm{SpO}_{2}$ ), minimum $\mathrm{SpO}_{2}$, total sleep time with $<90 \%$ oxyhaemoglobin saturation (TST90), Oxygen Desaturation index (ODI), apnoea duration, Sleep Arousal index in obstructive sleep apnoea (OSA) and their relationship with Apnoea-hypopnea index (AHI), Body Mass index (BMI), age and gender.

Materials and Methods: A total of 1.000 patients diagnosed with OSA using polysomnography between January 2018 and January 2019 were investigated retrospectively. All subjects underwent one night of laboratory-based polysomnography and were then classified in the polysomnography report as mild, moderate or severe OSA according to the $\mathrm{AHI}$ values.

Results: A significant relationship between $\mathrm{AHI}$ and $\mathrm{BMI}$, the male gender and age $(p<0.01)$ was noted. A strong negative correlation between mean nocturnal $\mathrm{SpO}_{2}$ and TST90 was also recorded. In all the oxymetric parameters, ODI was found to have a strong relationship with AHI. To distinguish between patients with and without apnoea, the mean nocturnal $\mathrm{SpO}_{2}$ cut-off point was found to be $93.6 \%$.

Conclusion: $\mathrm{A}$ unit increase of $\mathrm{BMI}$ increases the OSA risk by 1.5 times and being male increases OSA risk by 7.6 times. Ageing is also associated with higher AHI. A mean nocturnal oxygen saturation of $<93.6 \%$ is important in detecting apnoea in patients.

Keywords: Obstructive sleep apnoea, polysomnography, Body Mass index, males, oxygen
\end{abstract}

Öz

Amaç: Bu çalışmanın amacı, polisomnografideki solunum parametrelerini (ortalama noktürnal nabız oksihemoglobin satürasyonu $\left(\mathrm{SpO}_{2}\right)$, minimum $\mathrm{SpO}_{2}$, toplam uyku süresinde $\% 90$ altında oksihemoglobin satürasyonu (TST90), Oksijen Desatürasyon indeksi (ODI), apne süresi, Uyku Uyarılma indeksi) analiz ederek bu parametrelerin Apne-hipopne indeksi (AHI), Vücut Kitle indeksi (VKI), yaş ve cinsiyet ile ilişkisini araştırmaktır.

Gereç ve Yöntem: Ocak 2019 ve Ocak 2019 tarihleri arasında polisomnografi ile tanı alan 1,000 obstrüktif uyku apnesi (OUA) hastası retrospektif olarak incelendi. Tüm hastalara bir gece laboratuvar temelli polisomnografi yapıldı. Polisomnografi raporunda hastalar AHI değerlerine göre hafif, orta ve şiddetli OUA olarak sınıflandırıldı.

Bulgular: $\mathrm{AHI}$ ve $\mathrm{VKI}$, erkek cinsiyet ve yaş arasında anlamlı bir ilişki vardı $(p<0,01)$. Ortalama noktürnal $\mathrm{SpO}_{2}$ ve TST90 arasında güçlü bir negatif korelasyon vardı. Tüm oksimetrik parametreler içinde ODI'nin AHİ ile güçlü bir ilişkisi olduğu bulunmuştur. Apnesi olan hastaları apne olmayan hastalardan ayırmak için ortalama noktürnal $\mathrm{SpO}_{2}$ değeri için kesim (cut-off) noktası \%93,6 olarak bulundu.

Sonuç: VKI'nin 1 birim artışı obstrüktif uyku apne riskini 1,5 kat artııı, erkek olmak OSA riskini 7,6 kat artırır. Yaşlanma yüksek AHI ile ilişkilidir. Polisomnografi için başvuranlarda ortalama noktürnal oksijen satürasyonunun \%93,6'sının altında olması apne hastalarını saptamada önemlidir.

Anahtar Kelimeler: Obstrüktif uyku apnesi, polisomnografi, Vücut Kitle indeksi, erkekler, oksijen

\section{Introduction}

Obstructive sleep apnea (OSA) is a disorder that is characterized by obstructive apneas, hypopneas, and/or respiratory effortrelated arousals caused by repetitive collapse of the upper airway during sleep. OSA is the most common sleep-related breathing disorder.

OSA has a prevalence of no less than $2-4 \%$ of adults and is therefore frequently seen (1). 3.1-7.5\% of men, and 2.1$4.5 \%$ of women have the disorder according to a number of epidemiological studies (2-8). Respiration ceases periodically during sleeping, leading to the signs and symptoms of the disorder and accounting for its sequelae, e.g. a heightened risk profile for circulatory disease. There are associations between OSA and numerous other conditions, such as high blood pressure, diabetes mellitus, obesity, gastroesophageal reflux,

Address for Correspondence/Yazışma Adresi: Assoc. Prof. Sıdıka Deniz Yalım, Adana City Training and Research Hospital, Clinic of Otolaryngology, Adana, Turkey Phone: +90 5312409313 E-mail: denizmicozkadioglu@yahoo.com ORCID-ID: orcid.org/0000-0001-7833-8421 Received/Geliş Tarihi: 06.05.2020 Accepted/Kabul Tarihi: 06.03.2021

${ }^{\circ}$ Copyright 2021 by Turkish Sleep Medicine Society / Journal of Turkish Sleep Medicine published by Galenos Publishing House. 
impotence, depression, and elevated levels of cardiovascular and cerebrovascular morbidity and mortality (9). Likewise in the study of Senel et al. (10) it was seen that metabolic syndrome components were clustered in OSA patients, therefore they should be followed closely and given high priority. Consequently, suspecting and diagnosing OSA is a key clinical imperative.

OSA prevalence appears to be increasing and may relate to the increasing rates of obesity or the increased detection rates of OSA. OSA severity varies with age, gender, and upper airway area (11). However, when we look at the literature the change in risk is variable. On the other hand, the prognosis for OSA could be improved by evaluating the major factors affecting OSA and treating OSA patients according to epidemiological characteristics and anatomical structures, but in our country the sleep medicine area is new and the studies with large patient populations from our country are few in number. The development of new techniques can provide additional data, but it is important to carefully analyze and apply the data to make an accurate diagnosis and plan the most effective treatment of the disease.

We aim to study 1.000 patients from our country investigating the risk factors of OSA and how much they add to the severity of the disease, analyze the respiratory parameters in the polysomnography (mean nocturnal pulse oxyhemoglobin saturation (mean nocturnal $\mathrm{SpO}_{2}$ ), minimum $\mathrm{SpO}_{2}$, total sleep time with oxyhemoglobin saturation <90\% (TST90), Oxygen Desaturation index (ODI), apnea duration, and the Sleep Arousal index in OSA and their relationship with AHI, $\mathrm{BMI}$, age and gender. We also we wanted to analyze all of the parameters to find one that could enable clinicians to predict OSA in patients admitted for polysomnography. In order to form a prediction model to screen patients who have high risk of OSA, we used cut-off values for patients with an AHI below 5 and patients with an $\mathrm{AHI}$ over 5 . This predictive information relating $\mathrm{SpO}_{2}$ to $\mathrm{AHI}$ could be used for screening or home-based testing of patients with complaints related to sleep disordered breathing or in phenotyping OSA.

\section{Materials and Methods}

Thousand OSA patients diagnosed with polysomnography between January 2018 and January 2019 were investigated retrospectively in this study. All the patients with a clinical indication for OSA were recruited. The study was approved by the local ethic commission. All subjects underwent one night of laboratory based polysomnography. All the recordings were made on a Grass-Comet Plus polysomnograph. The patients were classified according to the Apnea-hypopnea index (AHI) values in the polysomnography report. In accordance with the World Health Organization classification of OSA, patients with $\mathrm{AHI}<5$ were considered as no/minimal $\mathrm{OSA}, \mathrm{AHI}=5-15$ as mild OSA, patients with $A H I=16-30$ as moderate OSA and patients with $A H>30$ were classed as severe OSA (12). The $\mathrm{BMI}$ of the patients were classified as $B M l<18.5 \mathrm{~kg} / \mathrm{m}^{2}$ as underweight, $18.5-24.9 \mathrm{~kg} / \mathrm{m}^{2}$ as normal weight, $25-29.9 \mathrm{~kg} /$ $\mathrm{m}^{2}$ as overweight, $30-34.9 \mathrm{~kg} / \mathrm{m}^{2}$ as $1^{\text {st }}$ degree obese, $35-39.9$ $\mathrm{kg} / \mathrm{m}^{2}$ as $2^{\text {nd }}$ degree obese, and a $\mathrm{BMl}>40 \mathrm{~kg} / \mathrm{m}^{2}$ as $3^{\text {rd }}$ degree obese. The ages of the patients were classified as $0-18,18-65$ and 65 and above.

\section{Statistical Analysis}

SPSS version 21 and Medicalc 19.1.3 packet programmes were used for the data analysis. Normality control of continuous variables were performed by the Shapiro Wilk test. Parametric methods were used since the variables were compatible with normal distribution. Student's t-test was used for the comparison of the mean of two independent groups, OneWay Analysis of Variance and the Tukey post-hoc tests were used for comparison of the mean of two groups. Pearson correlation coefficients were calculated in the linear relationship between two continuous variables. The effects of $\mathrm{BMI}$, age and gender on $\mathrm{AHI}$ and mean nocturnal $\mathrm{SpO}_{2}$ were examined with univariate and multiple linear regression analysis. $\mathrm{ROC}$ analysis was used to determine mean nocturnal $\mathrm{SpO}_{2}$ cut-off point for $A H I<5$ and $A H I \geq 5$ patients. The statistical significance level was taken as 0.05 .

\section{Results}

Two hundred thirty seven female and 763 male patients participated in the study and the mean age of the patients was $45.17 \pm 11.91$. The demographic distribution of the patients are given in Table 1. The mean values of $\mathrm{AHI}$, mean nocturnal $\mathrm{SpO}_{2}$ minimum $\mathrm{SpO}_{2}, \mathrm{ODI}$, TST90, apnea duration and sleep arousal index are given in Table 2.

There was a statistically significant difference between $\mathrm{AHI}$ and mean nocturnal $\mathrm{SpO}_{2}$ values of underweight, normal, overweight, $1^{\text {st }}, 2^{\text {nd }}$ and $3^{\text {rd }}$ degree obese groups $(p<0.001)$. The $p$ values of the differences between the groups (pairwise comparison) are given in Table 3. There was a statistically significant difference between $\mathrm{AHI}$ and the mean nocturnal $\mathrm{SpO}_{2}$ values of age groups 0-18, 18-65 and 65 and above $(p<0.001)$ (Table 4). There was a significant difference between

\begin{tabular}{|l|l|l|}
\hline \multicolumn{3}{|l|}{ Table 1. The demographic distribution of patients } \\
\hline & Mean \pm SD n (\%) & Min-max \\
\hline Age & $45.17 \pm 11.91$ & $5-80$ \\
\hline $0-18$ & $12(1.2 \%)$ & - \\
\hline $18-65$ & $953(95.3 \%)$ & - \\
\hline 65 and above & $35(3.5 \%)$ & - \\
\hline Gender & $237(23.7 \%)$ & - \\
\hline Female & $763(76.3 \%)$ & - \\
\hline Male & $28.98 \pm 5.04$ & $17.3-58$ \\
\hline BMI & $3(0.3 \%)$ & - \\
\hline Underweight & $188(18.8 \%)$ & - \\
\hline Normal & $426(42.6 \%)$ & - \\
\hline Overweight & $260(26.0 \%)$ & - \\
\hline $1^{\text {st }}$ degree obese & $84(8.4 \%)$ & - \\
\hline $2^{\text {nd }}$ degree obese & $39(3.9 \%)$ & - \\
\hline $3^{\text {rd }}$ degree obese & \\
\hline SD: Standard deviation, BMI: Body Mass index & \\
\hline & & \\
\hline
\end{tabular}


males and females in terms of $\mathrm{AHI}(\mathrm{p}<0.001)$, but this difference was not observed in mean nocturnal $\mathrm{SpO}_{2}$ (Table 5). According to OSA classification of patients, there was a statistically significant difference between the mean nocturnal $\mathrm{SpO}_{2}$, apnea duration and sleep arousal index values of simple snoring, and mild, moderate and severe OSAS patients $(p<0.001)$ (Table 6). There was a very weak positive linear relationship between age

Table 2. Mean values of AHI, mean nocturnal $\mathrm{SpO}_{2^{\prime}}$ minimum $\mathrm{SpO}_{2^{\prime}}$ ODI, TST90, apnea duration and Sleep Arousal index

\begin{tabular}{|l|l|l|}
\hline & Mean \pm SD n (\%) & Min-max \\
\hline AHI & $28.22 \pm 25.97$ & $0.1-128.2$ \\
\hline Mean nocturnal $\mathrm{SpO}_{2}$ & $93.42 \pm 2.65$ & $66.8-98.3$ \\
\hline Minimum $\mathrm{SpO}_{2}$ & $78.96 \pm 9.29$ & $50-95$ \\
\hline ODI & $13.27 \pm 17.63$ & $0-165.7$ \\
\hline TST90 & $13.64 \pm 20.46$ & $0-99.5$ \\
\hline Apnea duration & $23.78 \pm 8.05$ & $0-60$ \\
\hline Sleep Arousal index & $0.53 \pm 1.52$ & $0-29$ \\
\hline $\begin{array}{l}\text { SD: Standard deviation, AHI: Apnoea-hypopnea index, ODI: Oxygen } \\
\text { Desaturation index }\end{array}$
\end{tabular}

and $\mathrm{AHI}, \mathrm{ODI}$ and SAT90. There was a weak negative linear relation between age, $\mathrm{SpO}_{2}$, and minimum $\mathrm{SpO}_{2}$. We did not find a direct relationship with age and apnea duration or arousal. We found a weak positive linear relationship between $\mathrm{BMI}, \mathrm{AHI}$ and ODI. There was a weak positive linear relationship between $\mathrm{BMI}$ and $\mathrm{SaO}_{2}$, minimum $\mathrm{SaO}_{2}$, and apnea duration. We did not find a linear correlation between BMI and arousal (Table 7).

In the univariate analysis, $\mathrm{BMI}$, age and gender were effective on $\mathrm{SpO}_{2}$ but when evaluated together considering their combined interactions it was seen in multiple linear regression analysis that they were all effective on $\mathrm{SpO}_{2}$.

In univariate analysis, 1 unit increase in BMI lead to an increase of 1.538 units in AHI. One unit increase of age caused an increase of 0.404 units in AHI. Being male caused an increase of 7.571 units in AHI. In multiple analysis, while one unit of BMI and age caused a 1.467 and 0.378 units increase, respectively, being male caused an increase of 9.949 units (Table 8).

In the univariate analysis, 1 unit increase in AHI lead to a 1.147 units decrease in the mean nocturnal $\mathrm{SpO}_{2}$. Also 1 unit decrease in age caused a 0.05 decrease in the mean nocturnal $\mathrm{SpO}_{2}$.

Table 3. $\mathrm{AHI}$ and mean nocturnal $\mathrm{SpO}_{2}$ values of underweight, normal, overweight, $1^{\text {st }}, 2^{\text {nd }}$ and $3^{\text {rd }}$ degree obese groups and pairwise comparisons

\begin{tabular}{|c|c|c|c|c|c|c|c|c|}
\hline BMI & Underweight & Normal & Overweight & $\begin{array}{l}1^{\text {st }} \text { degree } \\
\text { obese }\end{array}$ & $\begin{array}{l}2^{\text {nd }} \text { degree } \\
\text { obese }\end{array}$ & $\begin{array}{l}3^{\text {rd }} \text { degree } \\
\text { obese }\end{array}$ & & \\
\hline & $\begin{array}{l}\text { Mean } \pm \text { SD } \\
(\min -\max )\end{array}$ & $\begin{array}{l}\text { Mean } \pm \text { SD } \\
(\min -\max )\end{array}$ & $\begin{array}{l}\text { Mean } \pm \text { SD } \\
(\min -\max )\end{array}$ & $\begin{array}{l}\text { Mean } \pm S D \\
(\min -\max )\end{array}$ & $\begin{array}{l}\text { Mean } \pm \text { SD } \\
(\min -\max )\end{array}$ & $\begin{array}{l}\text { Mean } \pm \text { SD } \\
(\min -\max )\end{array}$ & $p$ & $\begin{array}{l}\text { Pairwise } \\
\text { comparison }\end{array}$ \\
\hline $\mathrm{AHI}$ & $\begin{array}{l}30.73 \pm 25.67 \\
(1.7-50.4)\end{array}$ & $\begin{array}{l}15.58 \pm 18.61 \\
(0.1-89.2)\end{array}$ & $\begin{array}{l}25.23 \pm 23.40 \\
(0.1-104.8)\end{array}$ & $\begin{array}{l}35.28 \pm 26.68 \\
(0.2-110.1)\end{array}$ & $\begin{array}{l}45.34 \pm 30.91 \\
(0.4-128.2)\end{array}$ & $\begin{array}{l}37.57 \pm 30.92 \\
(0.7-105.6)\end{array}$ & $<0.001$ & $\begin{array}{l}2-3(p<0.001) \\
2-4(p<0.001) \\
2-5(p<0.001) \\
2-6(p<0.001) \\
3-4(p<0.001) \\
3-5(p<0.001) \\
3-6(p=0.033) \\
4-5(p=0.014)\end{array}$ \\
\hline $\begin{array}{l}\text { Mean } \\
\text { nocturnal } \\
\mathrm{SpO}_{2}\end{array}$ & $\begin{array}{l}94.23 \pm 1.77 \\
(92.2-95.4)\end{array}$ & $\begin{array}{l}94.30 \pm 2.20 \\
(76.8-98.3)\end{array}$ & $\begin{array}{l}93.74 \pm 2.14 \\
(79.1-97.9)\end{array}$ & $\begin{array}{l}92.88 \pm 3.16 \\
(66.8-98.2)\end{array}$ & $\begin{array}{l}92.11 \pm 2.39 \\
(85.2-97.9)\end{array}$ & $\begin{array}{l}91.97 \pm 4.05 \\
(74.7-95.8)\end{array}$ & $<0.001$ & $\begin{array}{l}2-4(p<0.001) \\
2-5(p<0.001) \\
2-6(p<0.001) \\
3-4(p<0.001) \\
3-5(p<0.001) \\
3-6(p=0.001)\end{array}$ \\
\hline
\end{tabular}

\begin{tabular}{|c|c|c|c|c|c|}
\hline Age & $0-18$ & $18-65$ & 65 and above & & \\
\hline & $\begin{array}{l}\text { Mean } \pm \text { SD } \\
(\text { min-max })\end{array}$ & \begin{tabular}{|l|} 
Mean \pm SD \\
$($ min-max $)$
\end{tabular} & $\begin{array}{l}\text { Mean } \pm \text { SD } \\
(\text { min-max })\end{array}$ & $p$ & Pairwise comparison \\
\hline $\mathrm{SaO}_{2}$ & $96.34 \pm 1.20(93.8-97.6)$ & $93.43 \pm 2.66(66.8-98.3)$ & $92.13 \pm 1.87(86.9-94.7)$ & $<0.001$ & $\begin{array}{l}1-2(p<0.001) \\
1-3(p<0.001) \\
2-3(p=0.012)\end{array}$ \\
\hline
\end{tabular}


There was no significant difference in being male in terms of mean nocturnal $\mathrm{SpO}_{2}$ (Table 8).

When we calculated the relationships between the polysomnography parameters with the pearson correlation coefficient analysis, we found a negative strong linear correlation between mean nocturnal $\mathrm{SpO}_{2}$ and the TST90 ( $r=0.836$, $\mathrm{p}<0.001)$. There was also a positive strong linear relationship between $\mathrm{AHI}$ and ODI $(r=0.781, \mathrm{p}<0.001)$ (Table 9).

\begin{tabular}{|c|c|c|c|}
\hline & Male & Female & \\
\hline & $\begin{array}{l}\text { Mean } \pm \text { SD } \\
(\min -\max )\end{array}$ & $\begin{array}{l}\text { Mean } \pm \text { SD } \\
(\min -\max )\end{array}$ & $p$ \\
\hline $\mathrm{AHI}$ & $(0.1-128.2)$ & $(0.1-103.2)$ & $<0.001$ \\
\hline Mean nocturnal $\mathrm{SpO}_{2}$ & \begin{tabular}{|l|}
$93.38 \pm 2.56$ \\
$(66.8-98.2)$
\end{tabular} & $\begin{array}{l}93.55 \pm 2.93 \\
(74.7-98.3)\end{array}$ & 0.391 \\
\hline
\end{tabular}

\begin{tabular}{|c|c|c|c|c|c|c|}
\hline OSA & No/minimal & Mild & Moderate & Severe & & \\
\hline & $\begin{array}{l}\text { Mean } \pm \text { SD } \\
(\min -\max )\end{array}$ & $\begin{array}{l}\text { Mean } \pm \text { SD } \\
(\min -\max )\end{array}$ & $\begin{array}{l}\text { Mean } \pm \text { SD } \\
(\min -\max )\end{array}$ & $\begin{array}{l}\text { Mean } \pm \text { SD } \\
(\min -\max )\end{array}$ & $p$ & $\begin{array}{l}\text { Pairwise } \\
\text { comparison }\end{array}$ \\
\hline $\begin{array}{l}\text { Mean } \\
\text { nocturnal } \\
\mathrm{SpO}_{2}\end{array}$ & $94.65 \pm 1.67(88.6-98.3)$ & $94.16 \pm 1.82(86.3-98.2)$ & $93.82 \pm 1.69(85-97.6)$ & $92.05 \pm 3.29(66.8-97)$ & $<0.001$ & $\begin{array}{l}1-3(p=0.005) \\
1-4(p<0.001) \\
2-4(p<0.001)\end{array}$ \\
\hline $\begin{array}{l}\text { Apnea } \\
\text { duration }\end{array}$ & $23.73 \pm 11.66(0-60)$ & $21.08 \pm 6.17(0-48.9)$ & $22.98 \pm 7.22(0-42.4)$ & $26.12 \pm 6.52(12.6-58.3)$ & $<0.001$ & $\begin{array}{l}1-2(p=0.002) \\
1-3(p=0.003) \\
2-4(p<0.001) \\
3-4(p<0.001)\end{array}$ \\
\hline $\begin{array}{l}\text { Sleep Arousal } \\
\text { index }\end{array}$ & $0.20 \pm 0.56(0-3.9)$ & $0.41 \pm 0.99(0-6.6)$ & $0.42 \pm 0.96(0-6)$ & $0.86 \pm 2.19(0-29)$ & $<0.001$ & $\begin{array}{l}1-4(p<0.001) \\
2-4(p<0.001) \\
3-4(p<0.001)\end{array}$ \\
\hline
\end{tabular}

Table 7. The linear relations of age and $\mathrm{BMI}$ with $\mathrm{AHI}, \mathrm{SpO}_{2}$, minimum $\mathrm{SpO}_{2^{\prime}}$ apnea duration and arousal

\begin{tabular}{|l|l|l|l|l|l|l|l|l|}
\hline \multicolumn{2}{|l|}{} & AHI & SpO $_{2}$ & Minimum SpO & ODI & SAT 90 & $\begin{array}{l}\text { Apnea } \\
\text { duration }\end{array}$ & Arousal \\
\hline \multirow{3}{*}{ Age } & $\mathrm{r}$ & 0.185 & -0.226 & -0.205 & 0.135 & 0.155 & -0.007 & 0.056 \\
\cline { 2 - 9 } & $\mathrm{p}$ & $<0.001$ & $<0.001$ & $<0.001$ & $<0.001$ & $<0.001$ & 0.832 & 0.078 \\
\hline \multirow{2}{*}{ BMI } & $\mathrm{r}$ & 0.298 & -0.279 & -0.241 & 0.265 & 0.254 & -0.117 & 0.024 \\
\cline { 2 - 9 } & $\mathrm{p}$ & $<0.001$ & $<0.001$ & $<0.001$ & $<0.001$ & $<0.001$ & $<0.001$ & 0.450 \\
\hline \multicolumn{7}{|l|}{ Pearson Correlation Coefficient, BMI: Body Mass index, AHI: Apnoea-hypopnea index, ODI: Oxygen Desaturation index } \\
\hline
\end{tabular}

Table 8. The univariate and multipl linear regression analysis of $\mathrm{AHI}, \mathrm{SpO}_{2^{\prime}} \mathrm{BMI}$, age and gender

\begin{tabular}{|c|c|c|c|c|c|c|}
\hline & \multicolumn{3}{|c|}{ Univariate } & \multicolumn{3}{|c|}{ Multiple } \\
\hline & B & $p$ & $\mathbf{R}^{2}$ & B & $p$ & $\mathbf{R}^{2}$ \\
\hline \multicolumn{7}{|l|}{$\mathrm{AHI}$} \\
\hline Age & 0.404 & $<0.001$ & 0.034 & 0.378 & $<0.001$ & \multirow[t]{2}{*}{0.136} \\
\hline Gender (male) & 7.571 & $<0.001$ & 0.015 & 9.494 & $<0.001$ & \\
\hline BMI & -0.147 & 0.016 & 0.078 & -0.136 & $<0.001$ & - \\
\hline Age & -0.050 & 0.007 & 0.051 & -0.046 & $<0.001$ & 0.120 \\
\hline Gender (male) & -0.169 & 0.391 & 0.001 & -0.386 & 0.039 & - \\
\hline
\end{tabular}


According to $\mathrm{AHI}$ classification there was a statistically significant difference between the mean nocturnal $\mathrm{SpO}_{2}$ of $\mathrm{AHI}<5$ and AHI $\geq 5 \quad(p<0.001)$ (Table 10). To detect the cut-off point we analyzed the data by using ROC analysis. The cut-off point of mean nocturnal $\mathrm{SpO}_{2}$ was determined as 93.6 to distinguish apneic and non-apneic patients $(p<0.001)$ (Table 11 ). According to this value, $\mathrm{SpO}_{2}$ 's success in distinguishing those with snoring (mild, moderate and severe) was 52.35\%, and the normal separation success rate was $77.08 \%$ (Figure 1 ).

\section{Discussion}

When we look at the literature, several clinical risk factors are associated with OSA; including age, the male gender and BMI. However, how much these factors effect OSA risk is not clear. The prevalence of OSA increases from young adulthood through the sixth to seventh decade, then it appears to plateau (13). $95.3 \%$ of our patients were between $18-65$ years of age. There was a statistically significant difference between $\mathrm{AHI}$ and age. In addition, there was a significant difference between the mean nocturnal $\mathrm{SpO}_{2}$ and age, but this was a weak negative linear relationship $(r=-0.226, p<0.001)$.

According to Fietze et al.'s (14) study, the prevalence of OSA increases with age for both men and women, but women are

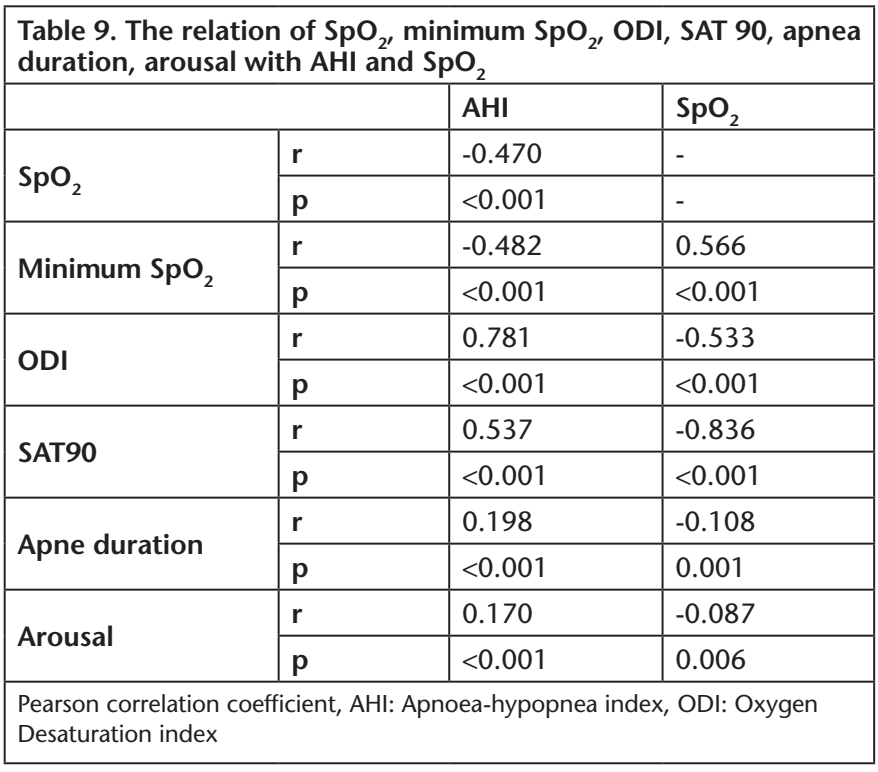

diagnosed with OSA at a later age than men. Also Fietze et al. (14) reported that gender, age, Body Mass index (BMI), waist-to-hip ratio, snoring, alcohol consumption (for women only) and cardiovascular diseases were positively associated with obstructive sleep apnea, but daytime sleepiness was not. Diabetes, hypertension and metabolic syndrome were positively associated with severe OSA. According to their study the clinical values of the female population was more strongly associated with OSA than in men. In their study, half of the patients had OSA, which was a very high prevalence. Furthermore, the OSA increase with age and presence of comorbid cardiovascular disease, was found to increase the mortality rate (14). Moreover, Hongyo et al.'s (15) findings suggest that the severity of OSA increase with age. Hongyo et al. (15) also reported that in the elderly patient group, male gender, BMI and age were independent risk factors of severe OSA.

The study of Bostanci et al. (16) provides evidence that elderly patients exhibit more severe and deeper nocturnal intermittent hypoxia than younger adults; independent of the severity of OSA, BMI, gender, and neck circumference. Hypoxia-related polysomnographic variables in geriatric patients may in fact reflect a physiological aging process rather than the severity of sleep disordered breathing (16).

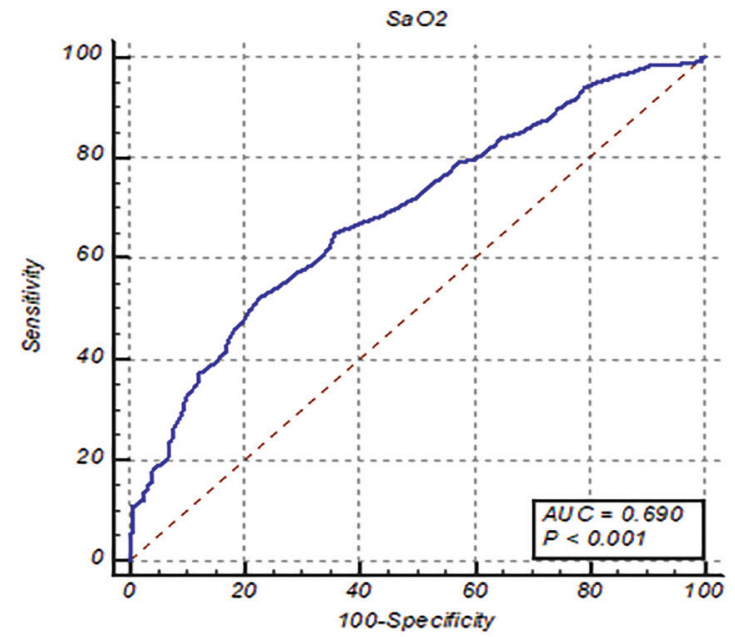

Figure 1. $\mathrm{SpO}_{2}$ 's performance to detect mild, moderate and severe apnea patients

AUC: Area under the curve

\begin{tabular}{|l|l|l|l|l|l|}
\hline Table 10. The comparison of $\mathrm{SpO}_{2}$ values of $\mathrm{AHI}<5$ and $\mathrm{AHI} \geq 5$ groups \\
\hline & $\mathrm{AHI}<5(\mathrm{n}=192)$ & $\mathrm{AHI} \geq \mathbf{5}(\mathrm{n}=\mathbf{8 0 8})$ & Min-max & $\mathrm{p}$ \\
\hline & Mean \pm SD & Min-max & Mean \pm SD & $88.6-98.3$ & $<0.001$ \\
\hline $\mathrm{SpO}_{2}$ & $93.13 \pm 2.76$ & $66.8-98.2$ & $94.66 \pm 1.67$ & \multicolumn{5}{l|}{} \\
\hline Student's t-test, SD: Standard deviation, AHI: Apnoea-hypopnea index &
\end{tabular}

\begin{tabular}{|l|l|l|l|l|}
\hline \multicolumn{4}{|l|}{ Table 11. ROC analysis to determine cut-off point of the mean nocturnal $\mathrm{SpO}_{2}$} \\
\hline AUC $(95 \% \mathrm{Cl})$ & Cut-off & Sensitivity $(95 \% \mathrm{Cl})$ & Specificity $(95 \% \mathrm{Cl})$ \\
\hline $0.690(0.660-0.718)$ & $\leq 93.6$ & $52.35(48.8-55.8)$ & $77.08(70.5-82.8)$ & $\mathbf{p}$ \\
\hline ROC analysis AUC: Area under the curve, Cl: Confidence interval \\
\hline
\end{tabular}


OSA is approximately two to three times more common in males than females, although the risk appears to be similar once women are postmenopausal (17). In our study, $76.3 \%$ of our patients were male, approximately three times more than females. Being male causes an increase of 7.71 units in AHI. The risk of OSA correlates well with BMI. In one study, a 10\% increase in weight was associated with a six-fold increase in the risk of OSA (14). In another study, moderate to severe OSA $(\mathrm{AHI} \geq 15)$ was present in $11 \%$ of men who were normal weight, in $21 \%$ who were overweight (BMI: 25 to $30 \mathrm{~kg} / \mathrm{m}^{2}$ ), and in $63 \%$ of those who were obese $\left(B M l>30 \mathrm{~kg} / \mathrm{m}^{2}\right)(18)$. Similarly, in women, OSA was present in $3 \%$ of patients who were normal weight, in $9 \%$ who were overweight, and in $22 \%$ who were obese (19). In our study $42.6 \%$ of OSA patients were overweight and $26 \%$ of the patients had $1^{\text {st }}$ degree obesity. According to our study, 1 unit increase in BMI leads to an increase of 1.538 units in AHI. There was a statistically significant difference between $\mathrm{AHI}$ and $\mathrm{BMI}$, and also between mean nocturnal $\mathrm{SpO}_{2}$ and BMI.

According to the OSA classification of patients, there was a statistically significant difference between the mean nocturnal $\mathrm{SpO}_{2}$, apnea duration and Sleep Arousal index values of simple snoring, mild, moderate and severe OSA patients (20). Kwubara suggests that the severity and frequency of decrease in $\mathrm{SpO}_{2}$ would be important indicators in identifying high-risk patients who are likely to develop cardiovascular events, specifically during sleep (21).

The study results of Bostanci et al. (22) provides supporting evidence that patients with similar AHI may have different ST90 values, which is the duration of hypoxia. Bostanci et al. (22) reports that the evaluation of OSA patients with both $\mathrm{AHI}$ and ST90 values together, gives more information about the prognosis of the patient. There was a strong negative correlation between mean nocturnal $\mathrm{SpO}_{2}$ and $\mathrm{ST} 90$ in this study also.

According to Xu et al. (23) in severe OSA, nocturnal and awake blood pressures are associated more with the hypoxic duration than with AHI. Nocturnal blood pressure fluctuation can be induced by hypoxia and arousal, especially by the hypoxia (23). The effect of sleep fragmentation on sympathetic discharge during wakefulness could contribute to intersubjective variability, age-related increases in muscle sympathetic nerve activity, associations between sleep deprivation and insulin resistance or insomnia and future cardiovascular events. Poor sleep behaviors have been found to be associated with metabolic dysfunction (21). Also the parameters from PSG or overnight oximetry such as AHI, ODI, ST90, mean and minimal $\mathrm{SpO}_{2}$, and longest apnea duration can be associated with postoperative complications, and may provide additional value in risk stratification and minimization (24).

\section{Study Limitations}

Being a retrospective study from a single center and the lack of data are the limitations of study. Also, except from BMI, the absence of important anthropometric measures such as neck circumference or waist-hip ratio measurements, are other limitations. Prospective multicenter studies with more data will help to reveal cause-effect relationships more clearly.

\section{Conclusion}

There is a significant relationship between $\mathrm{AHI}$ and $\mathrm{BMI}$, the male gender and age. One unit increase of $B M I$ increases the OSA risk by 1.5 times, and being male increases OSA risk 7.6 times. In all the oxymetric parameters of PSG, ODI was found to have a strong relationship with $\mathrm{AHI}$. The mean nocturnal $\mathrm{SpO}_{2}$ cut-off point was found to be $93.6 \%$, and this cut-off value can be used to distinguish apneic patients from non-apneic. Further studies are necessary for the general applicability of our results.

\section{Ethics}

Ethics Committee Approval: The study was approved by the local ethic commission (date: 18.12.2019, no: 642).

Informed Consent: Informed consent was obtained.

Peer-review: Internally peer-reviewed.

Financial Disclosure: The author declared that this study received no financial support.

\section{References}

1. Young T, Palta M, Dempsey I, Skatrud I, Weber S, Badr S. The occurrence of sleep-disordered breathing among middle-aged adults. N Engl J Med 1993;28:1230-5.

2. Punjabi NM. The epidemiology of adult obstructive sleep apnea. Proc Am Thorac Soc 2008;5:136-43.

3. Bixler EO, Vgontzas AN, Lin HM, Ten Have T, Rein J, Vela-Bueno A, Kales A. Prevalence of sleepdisordered breathing in women: effects of gender. Am J Respir Crit Care Med 2001;163:608-13.

4. Bearpark H, Elliott L, Grunstein R, Schneider H, Althaus W, Sullivan C. Snoring and sleep apnea. A population study in Australian men. Am J Respir Crit Care Med 1995; 151:1459-65.

5. Duran J, Esnaola S, Rubio R, Iztueta. Obstructive sleep apneahypopnea and related clinical features in a population-based sample of subjects aged 30 to 70 yr. Am J Respir Crit Care Med 2001;163:685-9.

6. Ip MS, Lam B, Tang LC, Lauder IJ, Ip TY, Lam WK. A community study of sleepdisordered breathing in middle-aged Chinese women in Hong Kong: prevalence and References gender differences. Chest 2004; 125:127-34.

7. Kim J, In K, Kim J, You S, Kang K, Shim J, Lee S, Lee J, Lee S, Park C, Shin C. Prevalence of sleep-disordered breathing in middle-aged Korean men and women. Am J Respir Crit Care Med 2004;170:1108-13.

8. Udwadia ZF, Doshi AV, Lonkar SG, Singh Cl. Prevalence of sleepdisordered breathing and sleep apnea in middle-aged urban Indian men. Am J Respir Crit Care Med 2004;169:168-73.

9. Asha'ari ZA, Hasmoni MH, Rahman JA, Yusof RA, Ahmad R. The association between sleep apnea and young adults with hypertension. Laryngoscope 2012;122:2337-42.

10. Senel MY, Yuceege MB, Firat $H$. The role of the metabolic syndrom criterias to determine moderate to severe sleep apnea patients. J Turk Sleep Med 2020;7:118-23.

11. Lee W, Nagubadi S, Mokhlesi B. Epidemiology of obstructive sleep apnea: a population-based perspective. Expert Rev Resp Med 2008;2:349-64.

12. Kapur VK, Auckley DH, Chowdhuri S, Kuhlman D, Mehra R, Ramar K, Harrot CG. Clinical practice guideline for diagnostic testing for adult obstructive sleep apnea; an American Academy of Sleep Medicine Clinical Practice Guideline. J Clin Sleep Med 2017;13:479-604. 
13. Kline LR, Collop N, Finlay G. Clinical presentation and diagnosis of obstructive sleep apnea in adults. UptoDate; 2019. Available from: https://www.uptodate.com/contents/clinical presentation and diagnosis of obstructive sleep apnea in adults.

14. Fietze I, Laharnar N, Obst A, Ewert R, Felix SB, Garcia C, Glaser $S$, Gloss M, Schmidt CO, Stubbe B, Völzke H, Zimmerman S, Penzel T. Prevelance and association analysis of obstructive sleep apnea with gender and age differences. Results of SHIP trend. J Sleep Res 2018;28:5:e12770. doi: 10.1111/jsr.12770.

15. Hongyo $K$, Ito $N$, Yamamoto $K$, Yasunobe $Y$, Takeda $M$, Oguro $R$, Takami Y, Takeya Y, Sugimoto K, Rakugi H. Factors associated with the severity of obstructive sleep apnea in older adults. Geriatr Gerontol Int 2017;17:614-21.

16. Bostanci A, Bozkurt S, Turhan M. Impact of age on intermittent hypoxia in obstructive sleep apnea: a propensity-matched analysis. Sleep Breath 2018;22:317-22.

17. Peppard PE, Young T, Barnet JH, Hla KM. Increased prevalence of sleepdisordered breathing in adults. Am J Epidemiol 2013;177:1006-14.

18. Young T, Skatrud J, Peppard PE. Risk factors for obstructive sleep apnea in adults. JAMA 2004;291:2013-6.
19. Peppard PE, Young T, Palta M, Dempsey J, Skatrud J. Longitudinal study of moderate weight change and sleep-disordered breathing. JAMA 2000;284:3015-21.

20. Tufik S, Santos-Silva R, Taddei JA, Bittencourt LR. Obstructive sleep apnea syndrome in the Sao Paulo Epidemiologic Sleep Study. Sleep Med 2010;11:441-6.

21. Kuwabara M, Tomitani N, Shiga T, Kario K. Polysomnography derived parameters as a determinant of nocturnal blood pressure profile in patients with obstructive sleep apnea. J Clin Hypertens 2019;20:1039-48.

22. Bostanci A, Turhan M, Bozkurt S. Factors influencing sleep time with oxygen saturation below $90 \%$ in sleep disordered breathing. Laryngoscope 2015;125:1008-12.

23. Xu J, Ding N, Zhang X, Wang N, Sun B, Zhang R, Xie X, Wan Z, Gu Y, Zhang S, Hong Y, Huang M, Meng Z. Nocturnal blood pressure flunctuationand associated influential factors in severe obstructive sleep apnea patients with hypertension. Sleep Breath 2018;22:1045-52.

24. Suen C, Ryan CM, Mubashir T, Ayas NT, Abrahamyan L, Wong J, Mokhlesi B, Chung F. Sleep study and oxymetry parameters for predicting postoperative complications in patients with OSA. Chest 2019;155:855-67. 